\title{
UTILISING 'MODERN SLAVE’ NARRATIVES IN SOCIAL POLICY RESEARCH
}

\begin{abstract}
Modern slavery has received somewhat limited attention in social policy (Craig 2018). Partially responding to this gap, while acknowledging the contested nature of the term 'modern slavery', this paper makes the case for the primary and secondary analysis of 'slave narratives' which provide experiential and agential accounts by those directly harmed by forced labour, coerced sex work, and other forms of exploitation. Analysis of a narrative interview with Sean, a (citizen-)victim of forced labour proved under s.71 of the Coroners and Justice Act 2009, demonstrates the multifaceted nature of labour exploitation and its multiple, severe, and long-lasting harms. That the form and structure of Sean's narrative of forced labour resembles those used in the abolitionist cause against antebellum slavery points to a certain timeless essence to forced labour exploitation. The paper concludes with implications for intervention.
\end{abstract}

\section{Keywords}

Exploitation, forced labour, victims, vulnerability, harm

\section{Corresponding author:}

Coretta Phillips, London School of Economics and Political Science, Department of Social Policy, Houghton Street, London, WC2A 2AE

Email: coretta.phillips@1se.ac.uk 


\section{Introduction}

Slavery, forced labour, servitude and human trafficking have been outlawed in all nation states, prohibited in the UK by the Modern Slavery Act 2015 and previously by the Coroners and Justice Act 2009 and the Palermo Protocol (2000). A recent systematic mapping exercise, commissioned by the UK's Independent Anti-Slavery Commissioner, identified a plethora of research from multiple disciplinary perspectives examining modern slavery across a range of forms, sectors, survivor types, geographical sites, and using diverse conceptualisations, theoretical foundations, and research methods (Bales et al., 2018). Craig (2018), however, in a recent UK Social Policy Association post has lamented social policy's lack of focus on slavery regarding it as a 'serious gap in our portfolio'. His clarion call was for social policy to fully engage with the problem through research, teaching, and political activism.

It is not that social policy has been uninterested in questions of slavery, particularly forced labour. Craig et al.'s (2007) review studied campaigning organisations involved in freeing slaves, and his later study examined official data, legislation, and interviewed UK stakeholders and service providers (Geddes et al., 2013). Where research access to survivors has been gained, there has been a predominant focus on migrant workers in economically precarious positions or ignorant of legal standards of employment (Anderson and Rogaly, 2005; Allamby et al., 2011; Scott et al., 2012; Strauss, 2012; Scott, 2018). Less is known about citizen-workers and their particular vulnerabilities. 
Collectively, this work has documented a spectrum of labour conditions from exploitative working relationships to forced labour, with Davies (2018) maintaining there has been an over-emphasis on the latter at the expense of understanding the former (see also Kagan et al., 2011). Attempts to articulate the distinctions within the continuum include the official ILO definition of forced labour incorporating 11 indicators (ILO 2012), extended to 19 by Scott et al. (2012) studying the food industry (see also Skrivankova, 2010; Paz-Fuchs, 2016; Scott, 2018). These included: threats or actual physical abuse; psychological harm; sexual harm; violence to friends or family; restrictions on movement; confinement to the workplace; debt bondage; withholding wages; retention of identity documents; threats of denunciation to authorities; surveillance; below National Minimum Wage pay; birth/descent into slave labour; abduction; sale of person; deception; exclusion from future employment; and from community life. Not all need to be present to constitute forced labour. But, as Craig et al. (2007) noted, it is still difficult to be definitive about what level of deception, low wages, coercion and so on, are necessary to be labelled as forced labour. It is this aspect which underlines the contested nature of modern slavery and which divides scholars.

For Bales (2004) modern slavery is culturally rooted and its forms are contextually varied, but it can include debt bondage, forced labour, coerced sex work, and involuntary military service. It is akin to transatlantic/antebellum slavery involving 'a state of control exercised over the slave based on violence or its threat, a lack of any payment beyond subsistence, and the theft of the labor or other qualities of the slave for economic gain' (Bales, 2005: 9). Now rarely depending on the legal, racialised 
ownership of human beings, it is facilitated by an abundance of potential slaves, low purchase costs, high profits, a short-term relationship, easy disposability, and is often obscured in legitimate workplace settings such as fields, building sites, clubs and domestic residences (Bales, 2004; cf. Bravo, 2007).

Conversely, O'Connell Davidson (2006), taking issue with Bales' conceptualisation, maintains that slavery has always represented a continuum of exploitation. She has been critical of the sensationalist political rhetoric around the term and the paternalistic representation of sex workers, in particular, as objects, victims, and slaves. Broad (2015: 1058) similarly rejects the binary discourse whereby the 'truly victimized are innocent, naive and powerless women and children in need of rescue from ruthless and sadistic men operating organized crime networks'. O'Connell Davidson (2010) goes on to question the logic of conflating labour exploitation with slavery when 'free' wage labour may bear the same hallmarks of forced labour, especially abject working conditions and pay (see also Anderson and Rogaly, 2005; Strauss, 2012; Lewis et al., 2015; Dwyer et al., 2016). Ollus (2015: 241) too notes the arbitrariness of the distinction as 'victims of both wrongs feel the same shame, pain, dislocation, lack of freedom, anger and humiliation'.

O'Connell Davidson (2010) and other critical scholars, such as Anderson and Rogaly (2005) and Lerche (2007), have been scathing of state affirmations of the intention to punish modern slavery offenders while obfuscating the state's contributory role in such practices through neoliberal economic policies and restrictive immigration controls (see also Anderson, 2012; Scott, 2018). Geddes et al. (2013), like others, have 
pointed to structural features of the economy which facilitate labour exploitation including flexibility, the contracting out of public services, the lengthening of supply chains, informal cash-in-hand practices, the availability of a cheap migrant workforce, reduced unionisation, and the low wage sector. Claims regarding the political co-optation of the modern slavery agenda to promote anti-Muslim sentiments have also been made (Murphy, 2015a).

There is a further problem that comes with the implicit tethering of contemporary practices of forced labour, trafficking and servitude to their perceived antebellum/transatlantic forerunners, according to O'Connell Davidson (2010). Too sharp a distinction between what counts as 'slavery' and 'freedom' can promote only deserving victims of slavery as worthy while others are deemed undeserving of social rights, justice and equality. Finally, Bravo (2007) finds problematic the deliberately evocative invocation of old (antebellum/transatlantic) slavery as analogous to new (modern) slavery, because it diminishes the horror of the former and its ongoing relevance for US racial politics.

Keeping these critiques in mind, this article nonetheless shares the pragmatic view of Paz-Fuchs (2016: 761) that 'particular elements associated with the core concept of slavery are still visible today, and in a manner that demands our attention'. While acknowledging the need for definitional clarity and robust operationalisation, he also accepts the rhetorical value of the term modern slavery for campaigning and legal purposes, and its' potential for expanding the rights and protections of workers, migrant and domestic, and all those at risk of labour exploitation in any form. 


\section{The value of slave narratives}

Social policy as a discipline has always studied empirical realities amidst competing state discourses and the political rhetoric of campaign organisations. Indeed, Williams' (2016) recent insightful review of critical perspectives highlights the fundamental importance of political activism to social policy thinking. She cites antiracist and black feminist community mobilisations around oppressive welfare provision in the 1980s that underscored how the state was directly implicated in exploiting migrant labour in the post-war welfare settlement.

Social policy has also given primacy to first person accounts, privileging the sensemaking and agency of individuals in their experiences of inequality and as recipients of welfare services. It is in this context that the value of slave narratives for social policy can be appreciated, not least because they have had a rather chequered past in some academic disciplines. Before the 1970s, historians studying transatlantic/antebellum slavery, for example, considered slave narratives to be inferior polemics or of doubtful authenticity (Nichols, 1971). Yet such stories revealed the textured world of slavery from the perspectives of those held in human bondage, illuminating its institutional structure and its deep and profound pains. These testimonies can be regarded as representations of black men and women writing themselves individually and collectively into being, at a time when their status as chattel denied their humanity. The narratives served as 'self-creation through representation, transferred to writing through the metaphor of voice' (Davis and Gates Jr, 1984: xxxi), while simultaneously demonstrating their authors' intellect 
and common humanity. Slave narratives also performed the avowedly political function of fermenting opposition to slavery as abolitionist propaganda. Today, scholars too support survivors being able to 'plead their own cause', to submit to public record their testimony in words of their choosing (Bales and Trodd, 2008). In fact, for Slaughter (1997), fundamental to $20^{\text {th }}$ century human rights law has been a commitment to the human subject to narrate their life story.

It seems likely, as Murphy (2015b) suggests, that we are now witnessing a revival of the slave narrative tradition, and like before such accounts remain essential fodder for abolitionist causes. Contemporary slave narratives have been collated from government reports, materials provided by third sector organisations, campaign groups, survivor networks, memoirs, autobiographies, newspaper interviews, and social media (Bales and Trodd, 2008; Johnson, 2013; Murphy, 2014, 2015a, 2015b). They have enormous secondary research potential for social policy, enabling an exploration of individual and collective realities of harmful exploitation. Slave narratives permit a critical examination of the degree and nature of control exerted in labour relationships, and to appreciate how these are understood and lived by those subject to them. This can allow a further interrogation of the validity of the Bales and O'Connell Davidson conceptual positions through the articulation of lived experiences untied to official definitions. And if Johnson (2013: 246) is right and 'narratives serve as perhaps the most important tool for fighting slavery in the twenty-first century because of the depth and breadth of information they provide, the turning points they identify, the awareness they raise, the empathy they evoke, and the action they demand', they also have the potential to affirm a political 
coalition between social policy scholars and activists seeking social change.

Like any archival or secondary source materials, however, slave narratives must be interpreted within the situational context in which they were produced. Those published commercially for popular audiences or with political objectives in mind, require careful scrutiny if they are to be used for academic research, but this is an age-old concern. Given ideological and institutional support for chattel slavery, transatlantic/antebellum slave narratives' methodological weaknesses were scrutinized by political, religious and literary critics, including Southern whites and scholars alike. The former were keen to filter out fraudulent narratives, and the latter were concerned about the skew towards exceptional slaves like Sojourner Truth, Frederick Douglass and Olaudah Equiano, and the under-representation of illiterate, female, fugitive, rural, field, and lower Southern state slaves (Davis and Gates Jr, 1984; Blassingame, 1977). Blassingame (1977: liii) has also challenged the reliability of the 2,300 postbellum ex-slave narratives collected under the auspices of the Federal Writers' Project in the 1930s. Poorly constructed questions, memory and age of sample issues, as well as selective transcription, meant improbable reflections such as "Yes, sir, Boss Man, de niggers wuz treated good in slabery times en wuz trained up right, ter wuk, en obey, en ter hab good manners"' were often recorded (Woodward, 1984: 51-52).

Moreover, narratives aim for listeners to be affectively connected to the dramatic experiences of the narrator, to feel both compassion and solidarity (Burchardt, 2016). 'The voice that speaks intimately of human rights violations calls out to us and asks 
us to intuit suffering, to identify with it for just long enough to attempt to comprehend and then to act', Murphy suggests (2015a: 106). Indeed, Davis and Gates (1984) maintain that antebellum slave narratives' popular literary function shared with the novel the aim of thrilling readers with tales of heroism in the midst of extreme adversity. As such, their emotionally charged nature and the associated potential to facilitate 'narrative advocacy' (Johnson, 2013) may raise concerns about objectivity. Narratives collected through primary research are to be preferred then, but they present many of the same strengths and limitations. They require the researcher to acknowledge how access was gained and what this might mean for representativeness. Selection bias among those contacted via third sector organisations may mean such narratives differ systematically from those of hidden victims (Tyldum and Brunovskis, 2005).

Researchers must also act to dampen any voyeuristic impulses in audiences engaging in what Klarer (2005) has called 'humanitarian pornography', indulging prurient interests in the violence and mutilation of exploited bodies (Murphy, 2015b). Given the troubling social relations of research production (Oliver, 1992), there is a risk that slave narratives could be exploited for 'colourful quotes' rather than for the material improvement of those subjugated (Bennett and Roberts, 2004). Alienating those who 'tell their misery' may be avoided if situated within political activism (Beresford, 2002). Slave narratives can also serve as the foundation for emancipatory or participatory research. Agendas for research, policy, and practice, driven or controlled by participants' own understandings, unfiltered by researchers' objectives offer considerable promise for power-sharing and co-learning, although such work is 
not without its ethical and practical challenges (Beresford and Evans, 1999; Lister, 2002; Evans and Fisher, 1999; Banks et al., 2013). These include how to activate inclusive and representative engagement, ensuring transparency, securing funding, and limiting the burden of participation (Bennett and Roberts, 2004).

Notwithstanding, the collective reflections enabled by the group sharing of stories can provide support and constructive exchange, detailing survivors' needs in the short, medium and long-term (Bennett and Roberts, 2004). McGrath and Rogaly's (2014) use of an animation inspired by research participants' stories illustrates another use for slave narratives as a social policy teaching resource to help unpack the validity of the term modern slavery.

Keeping these points in mind, this article further contributes to social policy scholarship by interrogating a life-history narrative interview with Sean, a (citizen)victim against whom conspiracy to require another person to perform forced or compulsory labour under s.71 of the Coroners and Justice Act 2009 was proved. Selfevidently, a single narrative interview is limited but its value lies in helping us understand the particular dynamics and contours of labour exploitation involving citizens where vulnerabilities other than migration status feature. It goes beyond the extant research in social policy which has relied heavily on migrant workers' testimonies, specifically in the food, mushroom, fishing and catering industries (Allamby et al., 2011; Scott et al., 2012). It illustrates the complexities of exploitative labour conditions in construction, particularly with regard to questions of consent, voluntariness, deception and coercion, while also detailing the aftermath of forced labour which has wide-ranging implications for social policy analysis and practice. 
The remainder of this paper, after a brief methodological note, is concerned with understanding Sean's experience of forced labour and teasing out the possibilities of intervening at crucial turning points.

\section{Sean's narrative of forced labour}

\section{Method}

Sean, a white British man in his 40s, was interviewed as part of a small qualitative study of 'doorstep fraud' (Phillips 2017). He was invited for interview because of his coerced involvement in defrauding consumers in the provision of property maintenance and construction services. Sean's contact details, provided by the police Senior Investigating Officer $(\mathrm{SIO})^{1}$ whose team rescued Sean and others four years previously, had been passed to the Lead officer for the National Trading Standards Doorstep Crime project to which the study had access (Phillips 2017). Sean's consent to be interviewed was undoubtedly linked to my being vouched for by the gatekeeper SIO - a man with hero status in Sean's eyes because of his role as liberator and his post-release support.

There can, of course, be no claims to Sean being representative of victims of forced labour. He was positively identified as a victim by law enforcement agencies, but as with other forced labour victims, the ratio of such victims to those unknown is itself unknown (Tyldum and Brunovskis, 2005). The Serious Organised Crime Agency (2013) identified 2,255 victims of modern slavery in 2012 and 7\% ( $\mathrm{n}=156)$, worked in block paving, tarmacking and construction, with a particularly prevalent subtype 
involving Traveller offenders, as in Sean's case (Cockbain and Brayley-Morris 2017). The possibility that enforcement actions of the kind Sean described were politically motivated to distract attention from high-profile evictions of Travellers from land they themselves owned, cannot be entirely discounted (Drummond, 2012; Siegel, 2016; Hall et al., 1978), although in his case action followed a suspicious report to the police.

The interview with Sean was rescheduled on three occasions in early 2015, seemingly reflecting ongoing instability in Sean's life with several temporary residential moves rather than reluctant participation (this was confirmed by Sean when asked repeatedly whether he wished to participate in the interview). The interview, in Sean's sparsely furnished flat, carefully followed disciplinary ethical guidelines, including with regard to informed consent and the opportunities to withdraw from participation at any time without giving a reason. To enable Sean to determine the content and flow of the interview, the interview was constructed with him being asked to talk about his past, present, and hopes for the future, rather than being directly asked about his victimisation. Sean responded comprehensively to any questions asked about his experiences, maintaining eye contact throughout, although he appeared somewhat apprehensive, a point I return to later. Sean's concern about his interview 'performance' persisted when contacted a week later to check how he was coping, and confirming his access to local health support services.. During this interaction, Sean seemed keen to ensure his account had been of value to the research, particularly in formulating ideas about the prevention of forced labour and doorstep fraud, and he seemed reassured to this effect. Undoubtedly, being formally 
labelled as a victim of forced labour by the police and courts shaped Sean's narrative, and this needs to be borne in mind in what follows.

Sean's backstory

It is particularly telling that Sean's life story conforms to many of the literary conventions including plot structure and linguistic devices of the original slave narrative tradition. For Olney (1984: 151) antebellum slave narratives were characterized by episodic coherence with 'virtually obligatory figures, scenes, turns of phrase, observances, and authentications'. Johnson's (2013) secondary analysis of 149 modern slave narratives collected by NGOs, journalists, and researchers has noted a similar structure and form (see also Murphy, 2015b). The temporally ordered sequence of scenes is summarised in Table 1.

\section{TABLE 1 ABOUT HERE}

When asked to talk about his past, present and future, Sean began with his place of birth and then 'I grew up mother, father'. The third sentence in he says, 'I lost my mother when I was 13 to breast cancer'. This can be read as both a suspenseful starting point for the narration and a turning point in Sean's life; his earlier childhood is never referred to. The extract below communicates a traumatic crisis, loss, and vulnerability, and for adolescent Sean, it reveals his angry rejection of prosocial activities. The depth of this formative experience is reinforced by external authorities, Sean's teachers:

...I thought she was going to recover because she had an operation to 
have her breast removed and everything but I didn't know it was terminal sort of thing...It sent me on a, I don't know, an anger thing because I totally changed...I was a swot, did all my exams and everything, and then when my mum died I started skiving [truanting] school, I started smoking, drinking. I started hanging around with all the rough people around school...All the teachers were shocked because it weren't like me at all...I went out of control.

After a period of family dislocation for Sean when his father remarries, he leaves home, and has a series of successful semi-and highly-skilled jobs of several years' duration. This discussion communicates Sean's commitment to conventional norms making his vulnerability to forced labour all the more incongruous. On his return to England, he recalls happy times caring for his 'brilliant father' until his death from cancer. Poignantly, Sean notes, 'I've lost all my family to cancer... my nan, my granddad, my aunties, my uncles.' This powerful sentiment implies that Sean's extreme grief, for a second time, propelled him towards personal crisis as he became a heavy drinker and homeless following the loss of his father's accommodation. At an early stage Sean presents a legitimatising rationale for his subsequent exploitation in an attempt to assuage any negative judgement of his blameworthiness, a practice common to crime victims (Shapland and Hall, 2007). He does this by juxtaposing his conventional commitment to education and employment with the pain and havoc wrought by parental bereavement.

\section{Analysing Sean's narrative}


Deeply inscribed in Sean's text is his fragility and vulnerability and it is this which is egregiously abused by offenders in his experience of forced labour. His narrative is somewhat unusual in that his personal biography was not of extreme poverty but was instead one foregrounded by childhood and adult trauma. This is an important reminder of the variation in indices of vulnerability that heighten the risk of exploitation. Sean's subsequent homelessness and estrangement from his family fixed his availability for exploitation on an ongoing basis, since the informal surveillance that might be possible from family members or neighbours regarding someone's whereabouts was absent. The lack of embeddedness in social networks is typically a feature of migrant workers' vulnerability to forced labour too (Allamby et al., 2011). These vulnerabilities highlight the need for health and welfare interventions to respond to the experiences of trauma and crisis.

\section{'Capture'}

This occurred when Sean was out drinking with homeless friends, and like many others involved in forced labour relationships, it was initially consensual. He was induced to go with 'The Travellers' when offered $£ 20$ for a day's work sweeping a yard, and he reports saying rather nonchalantly, '“Yeah, go on then," because I was half drunk and whatever' and later, 'I didn't know what to make of it', when he was shown to a caravan and advised to 'rest up'. The casual nature of this first interaction implies that anyone in his position could easily have been fooled into forced labour, and was emblematic of much in Sean's narrative where the extraordinariness of encounters were presented fatalistically. Again, Sean appears to be trying to absolve 
himself of any responsibility in his entrapment in efforts to neutralise and minimise what could be considered reductively and problematically as passivity. In fact, Sean's experience chimes with many others which reveals the absence of coercion and a voluntariness to go with offenders even when deception is suspected (Scott et al., 2012; Cockbain and Brayley-Morris, 2017).

Sean goes on to outline the block paving he is coerced into doing. Narrated as a reasonable request - "Do you want to go out doing some leafleting?", Sean agrees to this and to door-to-door canvassing to get business for the offenders. Two comments appear at this point - 'I didn't realise we were out from dusk until whenever it got dark at night' and, half-jokingly recognising his naivety about the frauds the offenders practised in their block paving business, noting 'Me oblivious, I didn't know' and 'I thought it was a legit business if you know what I mean?'

\section{Ongoing exploitation}

Extracts from across Sean's interview bring to mind Olney's (1984) contention that narratives depict exploitation through an episodic account recalling events without creative embellishment or emotional reflection:

You got up about 5:00 or 6:00 in the morning, go out and get on the job for 6:30, 7:00 and then just worked flat out up until 9:00 or 10:00 at night in the summer, until it was dark... Seven days a week...You didn't [get any breakfast or lunch]...You get immune to it. Plus you drank that much alcohol the night before that you didn't have appetite 
anyway...They used to give us $£ 10$ or something, or if we were lucky, $£ 20$ and we used to go and buy our food out of that and, whatever, and tobacco and that... the people that didn't find work [on block paving], were stuck in the yards [offenders' residences]. Trimming bushes, sweeping up, cutting grass, for nothing. You didn't get any pay at all...You had to beg them to get you food... I remember being on death's door with the flu and everything, I was really ill and they still had me out (working)...

Sean also reported the offenders withholding his benefits after requiring him to collect them from the Post Office, keeping his birth certificate, and only allowing him a mobile phone that received incoming calls to monitor his and others' work. He also recalled their isolation - 'we weren't allowed to speak to other people, associate with other people'. This enforced dependency was seldom entirely reliant on violent coercion, instead using subtle and sophisticated mechanisms of control linked to Sean's alcoholism. Yet Sean's recounting of the occasional violence meted out was similarly articulated without the rhythm of emotion, even when it involved his physical beating with a shovel which broke his arm and nose. The flat narration of 'the facts' likely reflected both the normalisation of Sean's powerlessness and his subjugation and the distress and despair with which he faced his victimisation four years on, a feature common to other victims of crime (Shapland and Hall, 2007). Clearly, several of the indicators of forced labour that Scott et al (2012) used were present - withholding wages, subsistence pay, overwork, restrictions on movement, and employer control and manipulation outside the employment relationship. 
The humiliating aspect of Sean's forced labour is in evidence in other parts of his narrative. For many, slavery in its modern form is unintelligible, a practice assumed extinct, and so narrators must justify their actions and reactions (Murphy, 2015b). Sean accomplished this by detailing the squalid and humiliating conditions in which he lived with other 'workmen'. There were no washing facilities other than an outside cold water tap, no flushing toilets, and Sean would use a nearby field or 'on the way to work in a morning, I used to stop at a 24-hour garage or something, use the toilets there'. Noteworthy here is Sean's reference to 'work', although such activity does not conform to normative or legal standards of employment and can hardly be considered anything other than extreme exploitation.

Reported speech as a linguistic device to provide authentication and a sui generis reality was used by Sean repeatedly. One example related to the constant surveillance he was subject to - 'They'd be on the phone every 10 seconds, "Where are you now? Where are you now?" Then they'd come round and check up on you' on the property maintenance jobs, emphasising the perpetual control exerted over him but also how Sean was not physically made to work. A second use of reported speech was the patently false claim that his seized benefits were being held legitimately - "Oh, we're just going to put it in a safe for you and save it up."

One of Sean's two escape attempts illustrated the restricted power that Sean had to end the relationship with the offenders and withdraw his labour. Leaving at sunlight having previously got his 'Giro' [welfare benefit] from another slave delivering the 
post ('He got a beating for that, actually; a bad one'), he travelled without a ticket and stayed in a cheap bed and breakfast. The tension in his story is further amplified when he goes to a shop and 'all of a sudden I heard my name...I thought, "My God, what's he doing here?" and he is identified by an offender's relative. Then, flatly delivered in a resigned tone, 'That was it, then, I was just recaptured again, wasn't I?'

Release and post-release

Finally, dramatic effect comes from Sean's narration of the unexpected rescue operation by the police which again uses reported speech to establish its veracity. Sean had in common with other victims of forced labour a mistrust of the police as well as confusion about his legal position (Doyle et al., 2018). Particularly significant too is Sean's lack of awareness of his criminal exploitation which is characteristic of forced labour:

... all I heard was screeching and all the handbrakes coming up...it was just like police everywhere and I went "Shit." I thought we'd done something wrong and the police said, “We're here to rescue you. We're going to take you to a safe place and that there's no need to be alarmed, we're here to help you." So we all got in the minibus and they had sandwiches, they had coffee, they had tea. They had beer because we were, like, dangerously alcoholics then...[the safe house was] surrounded by armed police, so then we thought, "Bloody hell, they are serious."...we had our own room in there; fresh bedding, televisions, the lot. 
Tellingly, like victims of intimate partner violence, Sean felt the need to clarify why he remained subjugated for so long (Dobash and Dobash, 1983). Mentioning his conversations with others who had implicitly or explicitly laid blame for his exploitation, making Sean complicit in his own forced labour and failure to leave the controlling environment, he said:

Everyone says, “Oh, I would have got away." Yeah right, mate...A few people have said it. "I would have got away." I don't think so...You can't explain. That's how it is. You know what it is, but you can't put it over in words. Until you've actually experienced it yourself, you don't know.

While Sean seems keen to underscore his blamelessness, he also demonstrates agency in managing to resist, to a degree his degraded status, communicating a sense of himself in which his masculinity is not totally undermined by his vulnerable victim role (Åkerström et al., 2011). Yet standing out too - for the first time in the interview - was Sean's forceful assertion that but for the police rescue he would still be a victim of forced labour:

If I was doing it for a legit company, or something, block paving, I'd be on $£ 100$ a day, blocking. I knew that but, again, it's getting away and whatever; can't do it. If the police hadn't rescued us, we'd still be there now. Fact [my emphases].

The switching of tenses here 'I knew that...can't do it' conveys a staunch defence of his actions and of his subjugation, in light of the earlier autobiographical narrative 
where his occupational success was a given. This could be seen as a sign of feeling shame, whereby according to Lejeune and Alex (1973), male crime victims may claim effective tactical actions instead of defending themselves in violent situations, thus averting discussion of their perceived impotence and diminished masculinity.

However, Sean also ascribes value to his forced labour demonstrating a resilience as he expresses pride in his workmanship:

I was their top blocker [block paver] in the end. All my jobs were solid. Even the police said that when we went round to look at them, none of them had sunk, they were absolutely solid jobs... I used to dig them out correctly. I used to put the correct amount of hard core in and sand and whatever and screed it so it was like glass, the sand was as flat as this floor, and then lay the blocks on.

This success earned Sean some autonomy and as the van driver he was sometimes able to 'fiddle the diesel' to buy extra food, cigarettes and alcohol. This was both a retaliatory gesture and an illustration of his moral selflessness as he used the money for himself and the other workmen whom he described as 'his family'. It is demonstrative of small acts of resistance which helped Sean maintain some semblance of a positive sense of self (Frank, 2010).

Since his release Sean had been in hospital for treatment for his damaged liver from alcohol abuse. He was also taking anti-depressant medication and fear, anxiety and insecurity were palpable constants in his life as has been found with others experiencing labour exploitation, and indeed, other forms of crime (Scott et al., 2012; 
Shapland and Hall, 2007; Hanson et al., 2010; Cockbain et al., 2018):

I'm still worried now about retaliation, to this day. I'm still nervous going out on my own. I never leave home without a mobile phone. I've got [SIO] on speed dial... I'm just trying to get on with my life, but I've always got them in the back of my mind, every time I go out. Even if I go to the shop here [new residential location 100 miles away]...I'm always looking over my shoulder, every day, every day. I'll never, ever, ever get out of that, I don't think. Ever... I'm better locked up, like, in a house where I haven't got to see anybody, or whatever... So every time I forget it and then I go in for a counselling session and I'm bringing it all back up, and then I'm depressed again for the next two or three weeks, or whatever. It gets me anxious again.

Sean's narrative then lacked hope that his life could proceed positively, indicating he 'was still trapped on the side of servitude even after liberation' (Bales and Trodd, 2008: 6), his self in stasis, emphasising that liberation is a process and not a discrete event (cf. van Dijk, 2009). Still haunted by his experiences, and then re-engaging with his victimisation during the research interview meant it was necessary at that point to draw the interview to a close to avoid secondary victimisation. This is a reminder of the long-standing psychological harm wrought by forced labour many years after the victimisation and the conclusion of criminal proceedings (Scott et al., 2012). It also underlines the need for welfare services across several domains, including housing, health care, and victim support.

\section{Implications for research and social policy}


This paper began by arguing for the use of slave narratives in social policy research. By engaging with the extant literature outside social policy, it contextualised the political value of such compelling accounts in the movement to abolish antebellum/transatlantic slavery, while also examining their renewed use in understanding the contours of contemporary labour exploitation. As relatively few studies have been able to secure primary access to victims, there are ample gains to be made from secondary analysis of slave narratives collected from a variety of sources, even taking into account their methodological limitations. Narrations of forced and other forms of exploitative labour provide the opportunity for an ongoing public conversation about, and political engagement with, the normative limits of employment practices and what constitutes 'decent employment' (ILO 2006; Skrivankova, 2010; cf. Strauss, 2012). Such narratives can also form the basis of awareness, advocacy, and training for an array of welfare professionals likely to come into contact with those at risk of labour exploitation.

O'Connell Davidson's (2010) insistence that we be less heavy-handed with the term 'modern slavery' is a point well-made. However, we should also not be afraid to weigh the value of 'slave narratives' as inherently personal and political statements about harmful exploitation. They offer a means to carefully document instances of exploitation which do and do not constitute criminal or the most serious acts but which are nonetheless deemed harmful and controlling by those experiencing them. The finding that narratives across time and space broadly share common features is significant. Sean's narrative accorded with the coherent structure and many of the motifs of storytelling present in transatlantic/antebellum and modern slave 
narratives. It points to a certain timeless essence to the manipulative appropriation of labour where individuals are commodified and dehumanized. Clearly there was a subtle yet all-encompassing nature to the control exerted over Sean, facilitated by the withholding of wages, physical isolation, constant surveillance, and the threat of violence. These aspects as Scott (2018) notes, underline the dangers of fetishising coercion in understanding forced labour. Narrative accounts provide an appreciation of how individuals may be exploited on their own volition, where control rather than coercion may be a more apt descriptor to portray the messiness of exploitative labour relationships. Whether Sean's experiences should be labelled as modern slavery or as an example of the flagrant, cynical, but largely legal, excesses of global capitalist labour commodification (Bales, 2004; O'Connell Davidson, 2006; O'Connell Davidson, 2010) may matter less if our interest is in responding to lived experiences of the intersecting harms of exploitation, vulnerabilities, and dependency (Hillyard et al., 2005; Scott, 2018).

This paper, while only based on a single interview, has also shed light on the particular exploitation of the vulnerabilities of citizens who are not at risk of denunciation to immigration authorities. Interventions responding to Sean's parental bereavement, alcoholism, and homelessness would have likely reduced his risk of exploitation as significant turning points in his narrative. It is probable, however, that there will be many disparate paths that heighten the risk of individuals' emotional and physical vulnerability, and assisting with these antecedent events are undoubtedly important in their own right, as well as potentially offering protection against exploitation. Apparent too is forced labour's physical, psychological and 
emotional harms which last well beyond the criminal processing of offenders. Sean's talk, framed by his official designation as a victim under s.71 of the Coroners and Justice Act 2009, reveals his inhabitation of his victim identity as someone innocently wronged, the suffering post-rescue a marked reminder of the ongoing devastating effects long after the victimisation occurred. Ongoing access to housing, physical and mental health care, legal advocacy, education, training, financial support, employment assistance, and community reintegration will be essential to survivors' wellbeing.

While Sean's narrative did point to his feelings of helplessness, his account also revealed small acts of resistance. Effectively, disempowered of the possibilities of physical resistance, 'fiddling the diesel' and other small acts were relished in denying total control over his life. The distinctive way in which Sean tried to communicate, sometimes rather defensively, that he was not culpable, blameworthy or passive in his exploitation, was also a sign of agency, as he resisted presumptions of complicity in his forced labour. Sean's narrative pointedly linked his oppressive experience to that of crime victims and we can therefore look to criminological research and practice to understand and respond to experiences of labour exploitation.

Cockbain et al.'s (2018) systematic review notes how little robust research there is on evaluating interventions to reduce human trafficking in Europe. Situational crime prevention techniques could be used to interrupt criminal opportunities for labour exploitation (Cockbain and Brayley-Morris, 2017). Examples include increasing the perceived effort it would require offenders to recruit the homeless and other 
vulnerable individuals. Targeted education warning of the risks of being approached while on the streets may be of value but the instability and complex needs of homeless populations would make public education programmes challenging in themselves. Increased surveillance by agencies including the police around hostels, soup kitchens and food banks might have an impact on disrupting offenders but it is unlikely such provision could be provided on a large scale (Cockbain and BrayleyMorris, 2017). Attempting to increase scrutiny in settings where there is greater exposure to the public could also be considered, in Sean's case at domestic residences where property maintenance is underway, but high rates of detection are again unlikely. It is here that learning about the motivations, opportunities, and decisionmaking of labour exploiters will be invaluable and this is an area where future research efforts should be directed.

\section{Acknowledgements}

My particular thanks go to Tim Newburn for his helpful comments on previous drafts of this paper. I would like to also thank Ben Bowling, Emma Caussil, Rod Earle, Jennifer Fleetwood, Alpa Parmar, Ken Pease, Paul Rock, and the three anonymous reviewers for their constructive critique.

\section{Funding}

Funding was received from National Trading Standards and LSE STICERD. 
Table 1. Descriptive Content of Antebellum and Modern Slave Narratives

\begin{tabular}{llc}
\hline Antebellum Slave Narrative & Modern Slave Narrative & Sean's Forced Labour Narrative \\
\hline Place but not date of birth & Family poverty/desperation & Bereavement and trauma \\
Sketchy account of parentage & Capture/sale or trade & Initially consensual \\
Slave master/overseer's cruelty & Violence and cruelty & Minimally discussed \\
Hardworking, loyal slaves & Differential reactions of slaves & Minimally discussed \\
Literacy barriers & X & X \\
Brutal but Christian slaveholder & Upright citizens revel as slaveholders & Offender frauds noted \\
Food/clothing/work/ living conditions & Food/clothing/work/ living conditions & Abject conditions \\
Barbarism of auctions/family separation & X & X \\
Slave patrols and failed escape attempts & Physical/psychological barriers to escape & Threat and dependency \\
& and failed attempts & Police operation \\
Successful escape/reception in a free state & Dramatic rescue by heroes & X
\end{tabular}


assistance

Reflections on slavery

Activism and public advocacy

X

Life after slavery

Psychological harms

Olney (1984)

Johnson (2013); Murphy (2015)

Interview: February 2015 


\section{References}

Åkerström M, Burcar V and Wästerfors D (2011) Balancing Contradictory

Identities - Performing Masculinity in Victim Narratives. Sociological

Perspectives 54(1): 103-124.

Allamby L, Bell J, Hamilton J, et al. (2011) Forced Labour in Northern Ireland:

Exploiting Vulnerability, York: Joseph Rowntree Foundation.

Anderson B (2012) Where's the Harm in That? Immigration Enforcement, Trafficking, and the Protection of Migrants' Rights. American Behavioral Scientist 56(9): 1241-1257.

Anderson B and Rogaly B (2005) Forced Labour and Migration to the UK, London: TUC.

Bales K (2004) Disposable People: New Slavery in the Global Economy. Revised Edition., Berkeley, CA: University of California Press.

Bales K (2005) Understanding Global Slavery: A Reader, Berkeley, CA: University of California Press.

Bales K, Hedwards B and Silverman B (2018) Modern Slavery Research: The UK Picture, London: Office of the Independent Anti-Slavery Commissioner and University of Nottingham's Rights Lab.

Bales K and Trodd Z (2008) To Plead Our Own Cause: Personal Stories by Today's Slaves, Ithaca. NY: Cornell University Press. 
Banks S, Armstrong A, Carter K, et al. (2013) Everyday Ethics in CommunityBased Participatory Research. Contemporary Social Science 8(3): 263-277.

Bennett F and Roberts M (2004) From Input to Influence: Participatory Approaches to Research and Inquiry into Poverty, York: Joseph Rowntree Foundation.

Beresford P (2002) User Involvement in Research and Evaluation: Liberation or Regulation? Part 2 Social Policy and Society 1(2): 95-105.

Beresford P and Evans C (1999) Research Note: Research and Empowerment. British Journal of Social Work 29(5): 671-677.

Blassingame J, W (1977) Slave Testimony: Two Centuries of Letters, Speeches, Interviews and Autobiographies, Bation Rouge, LA: Louisiana State University Press.

Bravo K, E (2007) Exploring the Analogy between Modern Trafficking in Human and the Transatlantic Slave Trade. Boston University International Law Journal 25(2): 207-295.

Broad R (2015) 'A Vile and Violent Thing': Female Traffickers and the Criminal Justice Response. British Journal of Criminology 55(6): 1058-1075.

Burchardt M (2016) The Self as Capital in the Narrative Economy: How Biographical Testimonies Move Activism in the Global South. Sociology of Health $\mathcal{E}$ Illness 38(4): 592-609.

Cockbain E, Bowers K and Dimitrova G (2018) Human Trafficking for Labour 
Exploitation: The Results of a Two-Phase Systematic Review Mapping the European Evidence Base and Synthesising Key Scientific Research Evidence. Journal of Experimental Criminology: 1-42.

Cockbain E and Brayley-Morris H (2017) Human Trafficking and Labour Exploitation in the Casual Construction Industry: An Analysis of Three Major Investigations in the UK Involving Irish Traveller Offending Groups. Policing: A Journal of Policy and Practice 12(2): 129-149.

Craig G (2018) No 20: Slavery Never Went Away: How Social Policy Can Help Eradicate This 21st Century Issue, 50th Anniversary Blog Series: SPA. http:/ / www.social-policy.org.uk/50-for-50/modern-slavery /

Craig G, Wilkinson M, Gaus A, et al. (2007) Contemporary Slavery in the UK, York: Joseph Rowntree Foundation.

Davies J (2018) From Severe to Routine Labour Exploitation: The Case of Migrant Workers in the UK Food Industry. Criminology \& Criminal Justice.

Davis C, T and Gates Jr HL (1984) Introduction: The Language of Slavery. In: Davis C, T and Gates Jr HL (eds) The Slave's Narrative: Texts and Contexts. New York, NY: Oxford University Press, xi-xxxiv.

Dijk JV (2009) Free the Victim: A Critique of the Western Conception of Victimhood. International Review of Victimology 16(1): 1-33.

Dobash R, E and Dobash R (1983) Violence against Wives : A Case against the 
Patriarchy, New York: New York : Free Press.

Doyle DM, Murphy C, Murphy M, et al. (2018) 'I Felt Like She Owns Me': Exploitation and Uncertainty in the Lives of Labour Trafficking Victims in Ireland. The British Journal of Criminology.

Drummond A (2012) Counterblast: How Many More 'Slaves' Like Kevin? Howard Journal of Criminal Justice 51(2): 207-209.

Dwyer P, Hodkinson S, Lewis H, et al. (2016) Socio-Legal Status and Experiences of Forced Labour among Asylum Seekers and Refugees in the UK. Journal of International and Comparative Social Policy 32(3): 182-198.

Evans C and Fisher M (1999) Collaborative Evaluation with Service Users. In: Shaw I and Lishman J (eds) Evaluation and Social Work Practice. London: Sage, 101-117.

Frank A, W (2010) Letting Stories Breathe: A Socio-Narratology, Chicago, IL: University of Chicago Press.

Geddes A, Craig G, Scott S, et al. (2013) Forced Labour in the UK, York: Joseph Rowntree Foundation.

Hall S, Critcher C, Jefferson T, et al. (1978) Policing the Crisis: Mugging, the State and Law and Order, London: Macmillan.

Hanson RF, Sawyer GK, Begle AM, et al. (2010) The Impact of Crime Victimization on Quality of Life. Journal of Traumatic Stress 23(2): 189-197. 
Hillyard P, Pantazis C, Tombs S, et al. (2005) Criminal Obsessions: Why Harm Matters More Than Crime, London: Crime and Society Foundation.

International Labour Organisation (2006) Decent Work: Objectives and Strategies, Geneva: ILO.

International Labour Organization (2012) ILO Indicators of Forced Labour, Geneva: ILO.

Johnson K, L. (2013) The New Slave Narrative: Advocacy and Human Rights in Stories of Contemporary Slavery. Journal of Human Rights 12(2): 242-258.

Kagan C, Lo S, Mok L, et al. (2011) Experiences of Forced Labour among Chinese Migrant Workers. York: Joseph Rowntree Foundation.

Klarer M (2005) Humanitarian Pornography:John Gabriel Stedman's Narrative of a Five Years Expedition against the Revolting Negroes of Surinam (1796). New Literary History 36(4): 559-587.

Lejeune R and Alex N (1973) On Being Mugged: The Event and Its Aftermath. Urban Life and Culture 2(3): 259-287.

Lerche J (2007) A Global Alliance against Forced Labour? Unfree Labour, NeoLiberal Globalization and the International Labour Organization. Journal of Agrarian Change 7(4): 425-452.

Lewis H, Dwyer P, Hodkinson S, et al. (2015) Hyper-Precarious Lives: Migrants, Work and Forced Labour in the Global North. Progress in Human Geography 
39(5): 580-600.

Lister R (2002) A Politics of Recognition and Respect: Involving People with Experience of Poverty in Decision Making That Affects Their Lives. Social Policy and Society 1(1): 37-46.

McGrath S and Rogaly B (2014) Researching "Slave Labour": An Experiment in

Critical Pedagogy. ACME:An International E-Journal for Critical Geographies 13(4):

630-633.

Murphy L, T (2014) Survivors of Slavery: Modern-Day Slave Narratives, New York, NY: Columbia University Press.

Murphy L, T (2015a) Blackface Abolition and the New Slave Narrative.

Cambridge Journal of Postcolonial Literary Inquiry 2(1): 93-113.

Murphy L, T (2015b) The New Slave Narrative and the Illegibility of Modern Slavery. Slavery \& Abolition 36(2): 382-405.

Nichols W, W (1971) Slave Narratives: Dismissed Evidence in the Writing of Southern History. Phylon 32(4): 403-409.

O'Connell Davidson J (2010) New Slavery, Old Binaries: Human Trafficking and the Borders of 'Freedom'. Global Networks 10(2): 244-261.

O'Connell Davidson J (2006) Will the Real Sex Slave Please Stand Up? Feminist Review 83(1): 4-22. 
Oliver M (1992) Changing the Social Relations of Research Production.

Disability, Handicap \& Society 7(2): 101-114.

Ollus N (2015) Regulating Forced Labour and Combating Human Trafficking: The Relevance of Historical Definitions in a Contemporary Perspective. Crime, Law E Social Change 63(5): 221-246.

Olney J (1984) '"I Was Born": Slave Narratives, Their Status as Autobiography and as Literature. In: Davis C, T and Gates Jnr HL (eds) The Slave's Narrative: Texts and Contexts. New York, NY: Oxford University Press, 148-175.

Paz-Fuchs A (2016) Badges of Modern Slavery. Modern Law Review 79(5): 757785.

Phillips, C (2017) The Trouble With Culture: A Speculative Account of the Role of Gypsy/Traveller Cultures in 'Doorstep Fraud', Theoretical Criminology: 1-22.

Scott S (2018) Labour Exploitation and Work-Based Harm, Bristol: University of Bristol Policy Press.

Scott S, Craig G and Geddes A (2012) Experiences of Forced Labour in the UK Food Industry, York: Joseph Rowntree Foundation.

Serious Organised Crime Agency (2013) UKHTC: A Strategic Assessment on the Nature and Scale of Human Trafficking in 2012 London: SOCA.

Shapland J and Hall M (2007) What Do We Know About the Effects of Crime on Victims? International Review of Victimology 14(2): 175-217. 
Siegel D (2016) Ethnicity, Crime and Sex Work: A Triple Taboo. In: Siegel D and de Wildt R (eds) Ethical Concerns in Research on Human Trafficking. London: Springer.

Skrivankova K (2010) Between Decent Work and Forced Labour: Examining the Continuum of Exploitation, York: Joseph Rowntree Foundation.

Slaughter J (1997) A Question of Narration: The Voice in International Human Rights Law. Human Rights Quarterly 19(2): 406-430.

Strauss K (2012) Coerced, Forced and Unfree Labour: Geographies of Exploitation in Contemporary Labour Markets. Geography Compass 6(3): 137-148.

Tyldum G and Brunovskis A (2005) Describing the Unobserved:

Methodological Challengesin Empirical Studies on Human Trafficking. International Migration 43(1/2): 17-34.

Williams F (2016) Critical Thinking in Social Policy: The Challenges of Past, Present and Future. Social Policy E Administration 50(6): 628-647.

Woodward C, Vann (1984) History from Slave Sources. In: Davis C, T and Gates Jnr HL (eds) The Slave's Narrative: Texts and Contexts. New York, NY: Oxford University Press, 48-58.

\section{Author Biography}

Coretta Phillips is an Associate Professor (Reader) at the LSE in the Department of Social Policy. Her research interests lie in the field of race, ethnicity, crime and social policy. 
${ }^{1}$ A five hour interview was also conducted with the SIO. 